rocks, the author stated, was impossible if petrological evidence was of any value. The author also produced many facts to show that the conglomerates at the base of the Cambrian constantly overlapped the different members of the series which he claimed to be of Pre-Cambrian age, and that the unconformity was very marked and to be clearly seen in many coast-sections. The couglomerates were shown also to contain well-rolled pebbles of all the series included under the names Dimetian, Arvonian, and Pebidian, as proved by careful microscopical examination of the fragments by Mr. T. Davies and himself. An Appendix, by Mr. Davies, describing the inicroscopic character of the rocks, accompanied the paper.

\title{
CORRESPONDENCE.
}

TRIGLYPHUS, FRAAS; AND TRITYLODON, OWEN.

SIR,-I have been favoured by Prof. Neumayr with an extract from the "Neues Jahrbuch für Mineralogie," 1884, containing a passage from the work by Prof. Fraas "Vor der Sündfluth," which I regret not to have seen, and of which $I$ add a translation. With the above passage Prof. Neumayr adds a woodcut of the fossil tooth in question :-

"Fraas describes in his work, "Before the Deluge," I a peculiar little tooth from the Bone-bed, near Stuttgart, under the name Triglyphus, and he supplies the above figured very accurate woodcut of this unique specimen, which was, unfortunately, afterwards lost.

"This Triglyphus corresponds in a marked manner with the Tritylodon from the Cape; both show exactly the same fundamental type, although there are differences in the structural details and there may be good reason for a generic separation. In both the tooth is subquadrate the upper (masticating) surface is divided by two deep furrows from the front backwards in to three longitudinal crests resembling each other, each of which is again divided by oblique incisions (cross furrows) into separate protuberances. It appears also that the number of those protuberances nearly corresponds, as the number in each row, "which come first in sight," is three, as well in the one as in the other specimen.

"Unfortunately we know only one tooth of Triglyphus, but it is sufficient by its marked configuration to confirm a very remarkable and close affinity between a South African and a central European "Trias mammal." ",

Richard OWEN.

\section{ARE THE BLACKDOWN BEDS THE EQUIVALENTS OF THE GREY CHALK AT DOVER?}

Srr,-A paper on British Cretaceous Nuculidæ was published in the Quarterly Journal of the Geological Society for February. In it I show (p. 142) that three out of four of the Grey Chalk species are identical with those of Blackdown and with no others. Mr. Downes has since this publication found what I believe to be the fourth species, named N.pectinata, var. creta, at Blackdown, so that all the Grey Chalk species are now known to be common to the two formations.

1 Vor der Sündfluth, p. 215. 
I think that had I seen Mr. Downes' specimen I should have separated it under a distinct specific name instead of considering it merely a variety. It is singular that Dr. Fitton included $N$. pectinata in his list of Blackdown fossils; but as no specimen was known, I thought it likely that a specimen of $N$. antiquata, exhibiting pectinate structure, and which is still preserved in his original collection at Bristol, had been mistaken for it. I had previously noticed Blackdown species in the Grey Chalk, and think that when allowance is made for the different quality of sea-bottom, and the much greater probable depth of the Chalk sea, enough species will remain in common to prove that the two formations are practically of about the same age, or that at least the Blackdown Beds are much newer than the Gault. J. Starkie Gardner.

\section{"ELEVATION AND SUBSIDENCE."}

Srr,-I either fail to comprehend Mr. Starkie Gardner's argument, or he seems strangely to misunderstand the value of the evidence afforded by the presence of stratified sand with marine shells at an elevation of 500 feet in Scotland. $\mathrm{He}$ seems to admit that it means the total disappearance of all ice below that level. Now this implies that the larger proportion of the ice-sheet, which he assumes was the cause of the depression of the land, had been entirely removed, and further that a very considerable part of it must have been floated off long before that degree of submergence was reached -assuming with Mr. Gardner that the land was depressed during glacial conditions, which is not the belief of the most competent authorities upon the glaciation of Scotland.

Mr. Gardner says that in the course of submergence "the Firth of 'Tay would in fact become a fiord." I do not wish to repeat Mr. Gardner's slighting phrase, but I really do not know what he means by that. 1 understand that fiord and firth are convertible terms, or perhaps that the latter is a fair attempt to spell out in English the Norse pronunciation of the former word. But what the Forth of Tay would actually become were the land depressed 500 feet would be part of a wide sea joining the North Sea to the Atlantic, and stretehing from the flanks of the Grampians to the Southern Uplands, a sea certainly studded with innumerable islands, but few if any of them of sufficient area to bear an ice-cap, and not only would the great central valley of Scotland be turned into an archipelago, while vast tracts all round the coast as well as the Great Glen (through which the Caledonian Canal passes) would be deeply submerged, but even the mountainous regions that remained would be invaded in all directions by great firths occupying what are now the highland glens.

But apart from this sweeping removal of the ice, foot by foot, as the land sank down, the load of ice would be proportionately lightened, so that it would really be an instance of depression accompanied by unloading, not, as the new theory demands, depression by loading, and in proportion to the amount of the loading.

Mr. Gardiner writes somewhat contemptuously of the phrase 